\title{
PENGARUH HARGA TERHADAP VOLUME PENJUALAN PADA INDUSTRI KRIPIK SINGKONG "KARUNIA" DI DESA MACANAN, KECAMATAN JOGOROGO, KABUPATEN NGAWI
}

\author{
Atok Khoirur Ridho \\ Mahasiswa Prodi Pendidikan Ekonomi IKIP PGRI Madiun
}

\begin{abstract}
Abstrak: Tujuan penelitian ini adalah yang pertama untuk mengetahui harga kripik singkong Karunia di Desa Macanan, Kecamatan Jogorogo, Kabupaten Ngawi, kedua untuk mengetahui volume penjualan pada industri kripik singkong Karunia, ketiga untuk mengetahui pengaruh harga terhadap volume penjualan pada industri kripik singkong Karunia di Desa Macanan, Kecamatan Jogorogo, Kabupaten Ngawi pada tahun 2012-2013. Populasi dalam penelitian ini berupa harga dan volume penjualan pada industri kripik singkong Karunia tahun 2007-2013 atau 72 bulan. Sampel dalam penelitian ini sebanyak 24 bulan yaitu tahun 2012-2013. Variabel bebas yaitu harga diambil dengan metode dokumentasi, dan variabel terikatnya adalah volume penjualan yaitu diambil menggunakan metode dokumentasi. Teknik analisa data penelitian ini menggunakan regresi linear sederhana, teknik analisa ini digunakan untuk mengetahui pengaruh harga terhadap volume penjualan pada industri kripik singkong Karunia di Desa Macanan, Kecamatan Jogorogo, Kabupaten Ngawi pada tahun 2012-2013. Hasil penelitian menunjukkan bahwa harga mempunyai pengaruh positif terhadap volume penjualan pada industri kripik singkong "Karunia" pada tahun 2012-2013. Hal ini diperoleh dari uji korelasi yang menunjukkan hasil nilai $r_{\text {hit }}$ adalah 0,660, nilai $r_{\text {tab }}$ sebesar 0,404. Hal ini berarti bahwa $r_{\text {hit }} \geq r_{\text {tab }}(0,660 \geq 0,404)$. Dapat dikatakan bahwa $\mathrm{H}_{0}$ ditolak artinya terdapat hubungan yang signifikan harga dengan volume penjualan pada industri kripik singkong "Karunia".
\end{abstract}

Kata Kunci: Harga, Volume Penjualan.

\section{PENDAHULUAN}

Di bidang ekonomi yang perkembangan dan persaingannya yang semakin ketat dan situasi yang tidak menentu, suatu industri kecil maupun industri besar mau tidak mau harus semakin jeli mengamati, mengikuti dan menganalisa persaingan usaha bila tidak ingin ketinggalan. Sampai saat ini, banyak industri atau usaha yang pada akhirnya bangkrut atau gulung tikar karena tidak mampu mempertahankan usahanya. Oleh sebab itu, suatu industri harus mampu membuat keputusan yang tepat dan teliti guna mempertahankan eksistensinya dalam dunia industri. Agar dapat mempertahankan eksistensinya tersebut, suatu industri harus dapat menetapkan harga produk seefektif mungkin untuk menekan penjualan yang nantinya akan berdampak pada tingkat volume penjualan.

Penjualan merupakan salah satu proses sangat penting di dalam proses pemasaran sebuah produk. Hal ini dikarenakan dengan penjualan maka akan dapat memperlancar perputaran arus produk yang dihasilkan industri, yang nantinya akan berdampak pada volume penjualan.

Harimurti Subanar (2001:142) menyebutkan penjualan adalah "kegiatan yang diupayakan oleh perusahaan".

Basu Swastha dan Ibnu Sukotjo (2002: 183) berpendapat bahwa "penjualan merupakan fungsi yang paling penting dalam 
pemasaran karena menjadi tulang punggung kegiatan untuk mencapai pasar yang dituju".

Freddy Rangkuti (2009:57) menyebutkan penjualan adalah "pemindahan hak milik atas barang atau pemberian jasa yang dilakukan penjualan kepada pembeli dengan harga yang disepakati bersama dengan jumlah yang dibebankan kepada pelanggan dalam penjualan barang/jasa dalam suatu periode akuntansi".

Penjualan merupakan tujuan utama dalam kegiatan industri yaitu untuk menjual produk yang dihasilkan kepada para konsumen. Oleh sebab itu, penjualan memegang peranan yang sangat penting bagi sebuah industri sehingga dapat memberikan penghasilan pada industri guna menunjang keberhasilan serta berkembangnya industri tersebut untuk lebih baik.

Basu Swastha dan Irawan (2008:141) berpendapat bahwa "analisa volume penjualan merupakan suatu studi mendalam tentang masalah 'penjualan bersih' dari laporan rugi-laba perusahaan (laporan operasi). Manajemen perlu menganalisa volume penjualan total, dan juga volume itu sendiri".

Berhasil atau tidaknya penjualan sebuah produk pada suatu industri dapat dilihat dari hasil volume penjualan yang didapat, dan industri tersebut dapat diketahui mengalami kerugian ataupun keuntungan tergantung dari tingkat keberhasilan dalam proses penjualan.

Pengukuran volume penjualan ini biasanya dalam bentuk angka-angka atas jumlah produk yang telah terjual setiap unitnya. Hal ini dipertegas oleh Freddy Rangkuti (2009: 57) yang menyatakan bahwa volume penjualan adalah "pencapaian penjualan yang dinyatakan secara kuantitatif dari segi fisik atau volume atau unit suatu produk. Volume penjualan merupakan sesuatu yang menandakan naik turunnya penjualan dan dapat dinyatakan dalam bentuk unit, kilo, ton atau liter".

Basu Swastha dan Irawan (2008: 141) berpendapat bahwa "analisa volume penjualan merupakan suatu studi mendalam tentang masalah penjualan bersih dari laporan laba rugi perusahaan (laporan operasi). Manajemen perlu menganalisa volume penjualan total, dan juga volume itu sendiri ".

Dari beberapa pendapat di atas, dapat disimpulkan bahwa penjualan merupakan aktivitas atau kegiatan pemasaran yang berinteraksi secara langsung dengan para konsumen, dengan tujuan terjualnya produk yang ditawarkan atau dengan kata lain pengalihan hak milik atas barang dimana uang sebagai gantinya. Melihat dari pengertian tersebut, maka dalam penjualan terdapat dua belah pihak yang saling berinteraksi yakni penjual dan pembeli. Interaksi dilakukan secara langsung dan bertujuan agar produk yang ditawarkan dapat terjual. Dari kegiatan jual beli tersebut, maka dapat diketahui volume penjualannya yang dinyatakan dengan jumlah unit yang terjual.

Ramalan penjualan yang tepat sangat dibutuhkan oleh industri/perusahaan dalam setiap tahap perencanaan bisnisnya, sehingga manajer pemasaran pada setiap industri/ perusahaan harus mempunyai ramalan penjualan.

Basu Swastha dan Irawan (2008:154) "Ramalan penjualan dimaksudkan untuk menentukan kuota, dipakai sebagai pedoman di dalam pengembangan produk, merencanakan promosi, dan mengalokasikan tenaga kerja”. Ramalan penjualan ini akan digunakan oleh beberapa bagian dalam suatu industri atau perusahaan dan itu sangat membantu dalam persiapan mereka.

Ramalan penjualan ini dibuat untuk jangka waktu tertentu dan biasanya ketepatan ramalan tersebut akan semakin berkurang atau semakin tidak pasti apabila periode waktu ramalannya semakin panjang dari waktu sekarang.

Basu Swastha dan Irawan (2008:156) menyatakan bahwa metode-metode peramalan penjualan yang dapat dipakai ada beberapa macam, yakni : 


\section{Pendapat menejer}

Pendapat menejer ini merupakan salah satu teknik peramalan yang banyak dipakai oleh perusahaan/industri. Teknik tersebut melibatkan pengumpulan pendapat dari sekelompok manajer yang sudah berpengalaman. Nampaknya, para pengusaha di sini lebih mengutamakan seni menaksirnya daripada analisa data secara statistik.

2. Pendapat salesman

Di sini, seorang salesmen dapat meramalkan volume penjualan untuk pembelipembeli yang berada di daerah operasinya. Ini semua tidak terlepas dari masalah peningkatan posisi salesman dalam manajemen industri/perusahaan, di samping juga masalah insentif yang akan diterimanya. Semakin besar volume penjualan yang dicapai, berarti semakin tinggi pula insetifnya.

3. Survei niat pembeli

Metode ini dilakukan dengan mewawancarai sejumlah pembeli untuk mendapatkan informasi tentang jumlah dan jenis produk yang diharapkan akan mereka beli untuk masa yang akan datang.

4. Model mathematic

Model peramalan ini biasanya menggunakan kombinasi dari beberapa variabel dalam bentuk persamaan sehingga sering diperlukan komputer dan tenaga-tenaga ahli.

5. Analisa time series

Analisa time series ini dapat digunakan untuk membuat suatu ramalan untuk masa mendatang dengan mendasarkan pada data penjualan yang lampau.

Harga adalah "salah satu alat pemasaran kunci yang digunakan organisasi untuk mencapai tujuan pemasarannya". Philip Kotler dan Nancy Lee (2007:80).

Ujang Sumarwan (2011:19) menyebutkan bdan mengalokasikan teumen adalah "biaya untuk mendapatkan produk yang dibutuhkannya, karena itu perusahaan harus mampu menetapkan harga produk yang dapat terjangkau oleh konsumen yang akan membeli produk tersebut".

Basu Swastha dan Irawan (2008:241) menyatakan bahwa "Harga adalah jumlah uang (tambahan beberapa produk kalau mungkin) yang dibutuhkan untuk mendapatkan jumlah kombinasi dari produk dan pelayanannya".

Philip Kotter dan Kevin Lane Keller (2008:151) menyatakan bahwa "harga adalah faktor positioning kunci dan harus diputuskan dalam hubungannya dengan pasar sasaran ".

Dalam strategi penentuan harga, manajer harus menetapkan dulu tujuan penetapannya. Menurut Basu Swastha dan Irawan (2008:241) tujuan penetapan harga "adalah berasal dari perusahaan itu sendiri yang selalu berusaha menetapkan harga barang dan jasa setepat mungkin". Dan dalam menetapkan harga produknya dengan tepat perusahaan mempunyai tujuan yaitu:

1. Meningkatkan volume penjualan

2. Mempertahankan dan memperbaiki Market Share

3. Stabilisasi harga

4. Mencapai target pengembalian investasi

5. Mencapai laba maksimum

Dari beberapa pendapat di atas bahwa harga merupakan sebuah nilai yang ditetapkan pada sebuah produk yang dinyatakan dalam bentuk rupiah, dan produk tersebut dijual kepada konsumen guna menutup biayabiaya produksi yang dikeluarkan oleh perusahaan, dan perusahaan bertujuan untuk memperoleh keuntungan atau laba dari hasil menjual produk-produk yang dihasilkannya.

Harga adalah salah satu alat pemasaran kunci yang digunakan organisasi untuk mencapai tujuan pemasarannya". Philip Kotler dan Nancy Lee (2007:80).

Harga merupakan unsur yang paling berpengaruh terhadap sebuah produk, dan produk tersebut dijual kepada konsumen guna menutup biaya-biaya produksi yang dikeluarkan oleh perusahaan, dan perusahaan bertujuan untuk memperoleh laba atau keuntungan dari hasil penjualan. Hal ini dipertegas 
oleh Henry Faizal Noor (2007:297) mengatakan bahwa harga adalah "unsur penting dalam menentukan pendapatan perusahaan, karena pendapatan atau total revenue, adalah hasil dari kali harga dengan kuantitas terjual". Di samping itu tinggi rendahnya harga juga akan mempengaruhi jumlah barang yang terjual.

Pengukuran volume penjualan ini biasanya dalam bentuk angka-angka atas jumlah produk yaupakan sebuah nilai yanitnya. Hal ini dipertegas oleh Freddy Rangkuti (2009:57) yang menyatakan bahwa volume penjualan adalah "pencapaian penjualan yang dinyatakan secara kuantitatif dari segi fisik atau volume atau unit suatu produk. Volume penjualan merupakan sesuatu yang menandakan naik turunnya penjualan dan dapat dinyatakan dalam bentuk unit, kilo, ton atau liter".

Telah disebutkan di muka dalam melakukan kegiatan produksi, suatu industri pastinya selalu menetapkan harga yang tepat pada produk yang dihasilkannya. Agar harga tersebut nantinya berdampak positif bagi industri, maka industri perlu berpikir secara bijak terkait dengan penetapan harga produknya yang akan dipasarkan kepada para konsumen. Apabila harga tersebut terus ditingkatkan dari bulan ke bulan, maka belum tentu dapat meningkatkan volume penjualan. Selama ini memang banyak industri yang beranggapan kalau harga ditingkatkan, maka volumatau kegiatan pemasaan meningkat. Diharapkan dengan dihasilkannya produk yang berkualitas baik dari bulan ke bulan, maka dapat meningkatkan volume penjual an.

\section{METODE PENELITIAN}

Tempat penelitian dilakukan di Industri Kripik Singkong "Karunia" di Desa Macanan, Kecamatan Jogorogo, Kabupaten Ngawi. Rancangan dalam penelitian ini menggunakan metode penelitian kuantitatif. "penelitian kuantitatif merupakan metode penelitian yang berlandaskan pada filsafat positivisme, digunakan untuk meneliti pada populasi atau sampel tertentu, pengumpulan data menggunakan instrument penelitian, analisis data bersifat kuantitatif/statistik, dengan tujuan untuk menguji hipotesis yang telah ditetapkan". (Sugiyono, 2010:14) Dengan menggunakan metode ini, maka dapat diketahui ada tidaknya pengaruh harga terhadap volume penjualan.

Dalam penelitian ini yang menjadi variabel bebas (X) adalah Harga variabel terikat (Y) adalah Volume Penjualan.

Adapun populasi dalam penelitian ini yaitu harga dan volume penjualan pada industri kripik singkong "Karunia" di Desa Macanan, Kecamatan Jogorogo, Kabupaten Ngawi sejak tahun 2007 sampai dengan tahun 2013 atau 72 bulan. Sampel dalam penelitian ini adalah harga dan volume penjualan yang dinyatakan dengan hasil penjualan pada industri kripik singkong "Karunia" di Desa Macanan, Kecamatan Jogorogo, Kabupaten Ngawi Tahun 2012-2013, Jadi sampel dalam penelitian ini sebanyak 24 bulan.

Teknik pengumpulan data untuk variabel bebas yaitu harga diambil dengan metode dokumentasi, dan variabel terikatnya adalah volume penjualannya itu diambil menggunakan metode dokumentasi. Teknik analisa data penelitian ini menggunakan regresi linear sederhana, teknik analisa ini digunakan untuk mengetahui pengaruh harga terhadap volume penjualan pada industri kripik singkong Karunia di Desa Macanan, Kecamatan Jogorogo, Kabupaten Ngawi pada tahun 2012-2013.

\section{HASIL PENELITIAN}

\section{Variabel Harga}

Deskripsi data variabel harga kripik singkong "Karunia" di Desa Macanan, Kecamatan Jogorogo, Kabupaten Ngawi pada tahun 2012-2013 selama 24 bulan, setelah diolah dengan statistik diskriptif diperoleh hasil sebagai berikut: (a) Nilai total skor sebesar 67800; (b) Nilai mean sebesar 2825; (c) Nilai median sebesar 2875; (d) Nilai modus sebesar 2200; (e) Standar deviasi 
sebesar 470,661; (f) Nilai minimum sebesar 2200; (g) Nilai maksimum sebesar 3500.

Dari analisis diskriptif di atas maka harga pada industri kripik singkong "Karunia" di Desa Macanan, Kecamatan Jogorogo, Kabupaten Ngawi pada Tahun 2012-2013, mempunyai nilai yang baik. Karena berdasarkan perolehan mean di atas dari N sebanyak 24, harga kripik singkong yang berada di atas mean ( $>2825)$ atau harga tinggi sebanyak $12 \mathrm{~N}$ atau $50 \%$, sedangkan yang yang berada di bawah mean $(<2825)$ atau harga rendah sebanyak $12 \mathrm{~N}$ atau $50 \%$.

\section{Variabel Volume Penjualan}

Deskripsi data volume penjualan kripik singkong "Karunia" di Desa Macanan, Kecamatan Jogorogo, Kabupaten Ngawi pada tahun 2012-2013 selama 24 bulan, setelah diolah dengan statistik diskriptif diperoleh hasil sebagai berikut: (a) Nilai total skor sebesar 130255; (b) Nilai mean sebesar 5427,29; (c) Nilai median sebesar 4950; (d) Nilai modus sebesar 2920; (e) Standar deviasi sebesar 1949,86; (f) Nilai minimum sebesar 2920; (g) Nilai maksimum sebesar 9560.

Dari analisis diskriptif di atas maka volume penjualan pada industri kripik singkong "Karunia" di Desa Macanan, Kecamatan Jogorogo, Kabupaten Ngawi pada tahun 2012-2013, mempunyai nilai berdasarkan perolehan mean di atas dari $\mathrm{N}$ sebanyak 24 harga kripik singkong "Karunia" yang berada di atas mean $(>5427,29)$ atau volume penjualan kripik singkong "Karunia" tinggi sebanyak $10 \mathrm{~N}$ atau $41,67 \%$, sedangkan yang berada di bawah mean $(<5427,29)$ atau volume penjualan rendah sebanyak $14 \mathrm{~N}$ atau $58,33 \%$

\section{Hasil Uji Korelasi}

Dari uji korelasi dapat diketahui bahwa hasil nilai $r_{\text {bitung }}$ adalah 0,660 sedangkan nilai $r_{\text {tabel }}$ sebesar 0,404. Hal ini berarti bahwa $r_{\text {hitung }}$ $>r_{\text {tabel }}(0,660>0,404)$. Dapat dikatakan bahwa $\mathrm{H}_{0}$ ditola $\overline{\mathrm{k}}$ artinya terdapat hubungan yang signifikan harga dengan volume pen- jualan pada Industri Kripik Singkong "Karunia" di Desa Macanan, Kecamatan Jogorogo, Kabupaten Ngawi pada tahun 2012-2013.

Di lain pihak juga didukung dengan analisis uji determinasi atau sumbangan variabel $\mathrm{X}$ terhadap $\mathrm{Y}$ yang dilihat dari nilai $\mathrm{R}^{2}$ ( $\mathrm{R}$ Square). Diperoleh nilai $\mathrm{R}^{2}$ sebesar 0,435 , artinya sumbangan harga $(\mathrm{X})$ terhadap volume penjualan (Y) sebesar 43,50\%, sedangkan sisanya yecara langsung dan berhi oleh faktor lain.

\section{Hasil Uji Fisher}

Dari hasil Uji Fisher nilai $\mathrm{F}_{\text {hitung }}$ sebesar 16,956 sedangkan nilai $\mathrm{F}_{\text {tabel }}$ dengan DF 1 dan residu 22 sebesar 4,30. Di lain pihak apabila dilihat dari nilai $\mathrm{Sig}_{\text {hit }}$ sebesar 0,000 dan nilai $\mathrm{Sig}_{\text {prob }}$ besarnya 0,05 . Hal ini berarti bahwa $\mathrm{F}_{\text {hitung }}>\mathrm{F}_{\text {tabel }}(16,956>4,30)$ atau $\mathrm{Sig}_{\text {hit }}<\mathrm{Sig}_{\text {prob }}$ $(0,00 \theta<0,05)$. Dengan demikian $\mathrm{H}_{0}$ ditolak, artinya harga berpengaruh terhadap volume penjualan pada Industri Kripik Singkong "Karunia" Desa Macanan, Kecamatan Jogorogo, Kabupaten Ngawi pada tahun 2012-2013.

penelitiān,

Dari hasil uji t Perolehan hasil nilai $t_{\text {hitung. }}$ sebesar 4,118 dengan $\mathrm{Sig}_{\text {hit }}$ sebesar 0,000, sedangkan $\mathrm{t}_{\mathrm{tab}}$ pada taraf nyata 0,05 sebesar 2,069. Hal ini dapat dikatakan $\mathrm{t}_{\text {hitung }}>\mathrm{t}_{\text {tinbel }}$ $(4,118>2,069)$ atau $\operatorname{Sig}_{\text {hit }}<\operatorname{Sig}_{\text {prob }}(0,000<$ $0,05)$, keadaan ini dapat dikatakan ada beda pengaruh harga dengan volume penjualan pada industri kripik singkong Karunia Desa Macanan, Kecamatan Jogorogo, Kabupaten Ngawi pada tahun 2012-2013.

Dari hasil analisis yang digunakan dalam uji $\mathrm{t}$ diperoleh persamaan regresi sebagai berikut: Y $\quad-2293,982+2,733$ X, artinya aik turunnȳa penjualan dinaikkan dengan $1 \%$, akan terjadi kenaikan volume penjualan sebanyak $2,773 \%$, apabila faktor yang lainnya dianggap konstan. 


\section{Simpulan Hasil Analisis}

Atas dasar hasil pengujian hipotesis dapat diambil simpulan sebagai berikut:

\section{Simpulan Uji Korelasi}

Dari uji korelasi dapat diketahui bahwa nilai $r_{\text {hitung }}$ adalah 0,660 sedangkan nilai $r_{\text {tabel }}$ sebesar 0,404. Hal ini berarti bahwa $r_{\text {hitung }}>$ $\mathrm{r}_{\text {tabel }}(0,660>0,404)$. Dapat dikatakan bahwa $\mathrm{H}_{0}$ ditolak artinya terdapat hubungan yang signifikan harga dengan volume penjualan pada Industri Kripik Singkong "Karunia" di Desa Macanan, Kecamatan Jogorogo, Kabupaten Ngawi pada Tahun 2012-2013.

Sedangkan apabila dilihat dari determinasi atau sumbangan variabel $X$ terhadap $Y$ yang dilihat dari nilai $\mathrm{R}^{2}$. Diperoleh nilai $\mathrm{R}^{2}$ sebesar 0,435 , artinya sumbangan harga $(X)$ terhadap volume penjualan (Y) sebesar $43,50 \%$, sedangkan sisanya yang $56,50 \%$ ditentukan oleh faktor lain.

Sesuai hipotesis yang diajukan dapat diperoleh simpulan bahwa ada hubungan harga dengan volume penjualan pada industri Kripik Singkong "Karunia" di Desa Macanan, Kecamatan Jogorogo, Kabupaten Ngawi pada Tahun 2012-2013. Berarti $\mathrm{H}_{0}$ ditolak, dan $\mathrm{H}_{1}$ diterima.

\section{Simpulan Uji Fisher}

Dari hasil analisis data yang telah dilakukan untuk uji Fisher diperoleh hasil bahwa nilai $F_{\text {hitung }}$ sebesar 16,956 sedangkan nilai $F_{\text {tabel }}$ dengan DF 1 dan residu 42 dan sebesar 4,30. Di lain pihak apabila dilihat dari nilai $\mathrm{Sig}_{\text {hit }}$ sebesar 0,000 dan nilai $\mathrm{Sig}_{\text {prob }}$ besarnya 0,05 . Hal ini berarti bahwa $\mathrm{F}_{\text {hitung }}>$ $\mathrm{F}_{\text {tabel }}(16,956>4,30)$ atau $\operatorname{Sig}_{\text {bit }}<\operatorname{Sig}_{\text {prob }}(0,000$ $<0,05)$.

Berdasarkan hal tersebut dapat disimpulkan bahwa $\mathrm{H}_{0}$ ditolak, artinya harga pengaruh terhadap volume penjualan pada Industri Kripik Singkong "Karunia" di Desa Macanan, Kecamatan Jogorogo, Kabupaten Ngawi pada Tahun 2012-2013.

\section{Simpulan Ujit}

Selain diperoleh persamaan regresi diperoleh nilai $\mathrm{t}$ sebesar 4,118 dengan sig sebesar 0,000 , sedangkan $\mathrm{t}_{\mathrm{tab}}$ pada taraf nyata 0,05 sebesar 2,069. Hal ini dapat dikatakan $t_{\text {hit }}$ $>\mathrm{t}_{\text {tab }}(4,118>2,069)$ atau $\mathrm{Sig}_{\text {hit }}<\operatorname{sig}_{\text {prob }}(0,000$ $<0,05)$ keadaan ini dapat dikatakan ada keadaan ini dapat dikatakan ada beda pengaruh harga dengan volume penjualan pada Industri Kripik Singkong "Karunia" di Desa Macanan, Kecamatan Jogorogo, Kabupauk uji Fisher diperoleh has013.

Dari hasil analisis yang digunakan dalam uji $\mathrm{t}$ diperoleh persamaan regresi sebagai berikut: Y $\quad-2293,982+2,733$ X, artinya apabila hā̄ga produk dinaikkan dengan $1 \%$, akan terjadi kenaikan volume penjualan sebanyak $2,773 \%$, apabila faktor yang lainnya dianggap konstan.

\section{PEMBAHASAN}

\section{Pembahasan Uji Korelasi}

Untuk uji korelasi diperoleh nilai $r_{\text {hitung }}$ adalah 0,660 sedangkan nilai $r_{\text {tabel }}$ sebesar 0,404 . Hal ini berarti bahwa $r_{\text {hitung }}>r_{\text {tabel }}(0,660$ $>0,404)$. Dapat dikatakan bahwa $\mathrm{H}_{0}$ ditolak artinya terdapat hubungan yang signifikan harga dengan volume penjualan pada Industri kripik singkonupakan sebuah nilai yananan, Kecamatan Jogorogo, Kabupaten Ngawi padalah salah satu alat

\section{Pembahasan Uji Fisher}

Untuk uji Fisher diperoleh hasil nilai $\bar{F}_{\text {hitung }}$ sebesar 16,956 sedangkan nilai $F_{\text {tabel }}$ dengan DF 1 dan residu 22 sebesar 4,30. Di lain pihak apabila dilihat dari nilai $\mathrm{Sig}_{\text {hit }}$ sebesar 0,000 dan nilai Sig prob besarnya 0,05. Hal ini berarti bahwa $\mathrm{F}_{\text {hitung }}>\mathrm{F}_{\text {tabel }}(16,956>$ 4,30) atau $\operatorname{Sig}_{\text {hit }}<\operatorname{Sig}_{\text {prob }}(0,000<0,05)$. Dengan demikian $\mathrm{H}_{0}$ ditolak, artinya harga berpengaruh terhadap volume penjualan pada Industri kripik singkong "Karunia" di Desa Macanan, Kecamatan Jogorogo, Kabupaten Ngawi pada tahun 2012-2013. 


\section{Pembahasan Uji t}

Untuk uji t diperoleh nilai $\mathrm{t}_{\text {hitung }}$ sebesar 4,118 dengan $\mathrm{Sig}_{\mathrm{hit}}$ sebesar 0,000, sedangkan $\mathrm{t}_{\text {tab }}$ pada taraf nyata 0,05 sebesar 2,069 . Hal ini dapat dikatakan $\mathrm{t}_{\text {hitung }}>\mathrm{t}_{\text {tabel }}(4,118>2,069)$ atau $\operatorname{Sig}_{\text {hit }}<\operatorname{Sig}_{\text {prob }}(0,00 \Theta<0,05)$. Keadaan ini dapat dikatakan ada beda pengaruh harga dengan volume penjualan pada Industri kripik singkong "Karunia" di Desa Macanan, Kecamatan Jogorogo, Kabupaten Ngawi pada tahun 2012-2013.

Dari hasil penelitian menunjukkan bahwa harga mempunyai hubungan sekaligus pengaruh terhadap volume penjualan. Artinya suatu industri harus dapat menetapkan harga produknya seefektif mungkin untuk menekan n kegiatan produksi, sua akan berdampak pada tingkat volume penjualan.

\section{PENUTUP}

\section{Simpulan}

Berdasarkan hasil analisis data dan pembahasan uji regresi di atas, dapat disimpulkan sebagai berikut.

Harga kripik singkong "Karunia" di Desa Macanan, Kecamatan Jogorogo, Kabupaten Ngawi pada tahun 2012-2013 selama 24 bulan, setelah diolah dengan statistik diskriptif diperoleh hasil sebagai berikut: (a) Nilai total skor sebesar 67800; (b) Nilai mean sebesar 2825; (c) Nilai median sebesar 2875; (d) Nilai modus sebesar 2200; (apat, dan industri tersebur 470,661; (f) Nilai minimum sebesar 2200; (g) Nilai maksimum sebesar 3500. Dari analisis diskriptif di atas maka harga pada industri kripik singkong "Karunia" di Desa Macanan, Kecamatan Jogorogo, Kabupaten Ngawi pada Tahun 2012-2013, mempunyai nilai yang seimbang. Karena berdasarkan perolehan mean di atas dari N sebanyak 24, harga kripik singkong yang berada di atas mean $(>2825)$ atau harga tinggi sebanyak $12 \mathrm{~N}$ atau $50 \%$, sedangkan yang berada di bawah mean $(<2825)$ atau harga rendah sebanyak $12 \mathrm{~N}$ atau $50 \%$.

Volume penjualan kripik singkong "Karunia" di Desa Macanan, Kecamatan
Jogorogo, Kabupaten Ngawi pada tahun 2012-2013 selama 24 bulan, setelah diolah dengan statistik diskriptif diperoleh hasil sebagai berikut: (a) Nilai total skor sebesar 130255; (b) Nilai mean sebesar 5427,29; (c) Nilai median sebesar 4950; (d) Nilai modus sebesar 2920; (e) Standar deviasi sebesar 1949,86; (f) Nilai minimum sebesar 2920; (g) Nilai maksimum sebesar 9560. Dari analisis diskriptif di atas maka volume penjualan pada industri kripik singkong "Karunia" di Desa Macanan, Kecamatan Jogorogo, Kabupaten Ngawi pada tahun 2012-2013, mempunyai nilai bei analisis diskriptif di aan di atas dari $\mathrm{N}$ sebanyak 24 harga kripik singkong "Karunia" yang berada di atas mean ( $>$ $5427,29)$ atau volume penjualan kripik singkong "Karunia" tinggi sebanyak $10 \mathrm{~N}$ atau $41,67 \%$, sedangkan yang berada di bawah mean $(<5427,29)$ atau volume penjualan rendah sebanyak $14 \mathrm{~N}$ atau $58,33 \%$.

Harga meman volume penjualan padap volume penjualan pada industri kripik singkong "Karunia" di Desa Macanan, Kecamatan Jogorogo, Kabupaten Ngawi pada tahun 2012-2013. Terbukti dari hasil analisis regresi yang memuat uji korelasi, uji F, dan uji t.

\section{Saran}

Karena harga terbukti mempunyai pengaruh teatan Jogorogo, Kabupa, maka saran yang dapat disampaikan kepada industri kripik singkoamatan Jogorogo, Kabcanan, Kecamatan Jogorogo, Kabupaten Ngawi yaitu:

1. Industri kripik singkong "Karunia" harus selalu menetapkan harga setepat mungkin agar dapat selalu meningkatkan volume penjualan pada produk yang dihasilkannya.

2. Biar pun bahan baku sangat dipengaruhi oleh musim industri kripik singkong "Karunia" harus selalu menetapkan harga seefisien mungkin sehingga volume penjualan akan tetap stabil.

3. Tidak menentunya harga bahan baku, 
maka industri kripik singkong "Karunia" harus tetap mengutamakan kualitas produknya dan menetapkan harga yang setepat mungkin sehingga volume penjualan akan sesuai apa yang diharapkan.

4. Industri kripik singkong "Karunia" harus selalu mempertimbangkan harga yang ditetapkan sesuai dengan biaya-biaya produksi yang sudah dikeluarkan, sehingga akan memperoleh laba atau keuntungan sesuai dengan apa yang diharapkan, sehingga industri kripik singkong "Karunia" akan selalu dapat berkembang dengan baik.

5. Bagi industri-industri yang lain, seharusnya dalam menetapkan harga produk yang dihasilkanberapa macam, yakni : mungkin, karena harga merupakan unsur yang sangat penting dalam menentukan pendapatan perusahaan, karena harga sangat berpengaruh terhadap volume penjualan pada sebuah produk.

6. Bagi penelitian yang akan datang sebaiknya mengadakan pengembangan penelitian ini dengan menggunakan variabel bebas selain harga. Karena selain harga masih banyak faktor lain yang mempengaruhi volume penjualan pada sebuah industri atau perusahaan.

\section{DAFTAR PUSTAKA}

Basu Swastha dan Ibnu Sukotjo. 2002. Pengantar Bisnis Modern. Yogyakarta: Liberty Yogyakarta.

Basu Swastha dan Irawan. 2008. Manajemen Pemasaran Modern. Edisi Ketigabelas. Yogyakarta: Liberty Yogyakarta.

Freddy Rangkuti. 2009. Strategi Promosi yang Kreatif dan Analisis Kasus Integrated Marketing Communications. Jakarta: PT. Gramedia Pustaka Utama.

Gabriel Amin Silalahi. 2003. Metodologi Penelitian Sosial dan Ekonomi. Sidoarjo: Citramedia.
Harimurti Subanar. 2001. Manajemen Usaha Kecil. Yindustri kripik singkonkarta.

Hendry Faizal Noor. 2008. Ekonomi Manajerial. Jlam bentuk angka-angk Persada.

Husein Umar. 2011. Metode Penelitian untuk Skripsi dan Tesis Bisnis. Jakarta: PT. Raja Grafindo Persada.

Iqbal Hasan. 2004. Analisis Data Penelitian Dengan Statistik. Jakarta: Sinar Grafika Offset.

Jaka Permana. 2002. Membangun Industri Kecil di Desa. Bandung: CV. Putra Setia.

Juliansyah Noor. 2011. Metodologi Penelitai maksimum sebesar 95nada Media Group.

Nanang Martono. 2010. Metode Penelitian Kuantitatif. Jakarta: PT. Raja Grafindo Persada.

Philip Kotler dan Kevin Lane Keller. 2008. Manajemen Pemasaran. 2008: PT. Glora Aksara Pratama.

Philip Kotler dan Nancy Lee. 2007. Pemasaran di Sektor Publik: PT. INDEK.

Sugiono. 201akan suatu studi mendalam dikan. Bandung: Alfabeta.

Suharsimi Arikunto. 2010. Prosedur Penelitian Suatu Pendekatan Praktik. Jakarta: PT. Rineka Cipta.

Sukardi. 2003. Metodologi Penelitian Pendidikan. Yioning kunci dan harus diara.

Tim IKIP PGRI Madiun. 2013. Pedoman Penulisan Skripsi. Madiun: IKIP PGRI Madiun.

Uhar Suhasaputra. 2012. Metode Penelitian. Baah produk yang dinyataa.

Ujang Sumarwan. 2011. Perilaku Konsumen. Bogor: Ghalia Indonesia.

Usman Rianse dan Abdi. 2012. Metodologi Penelitian Sosial dan Ekonomi Teori $d$ i sebanyak $12 \mathrm{~N}$ atau $50 \%$, se 